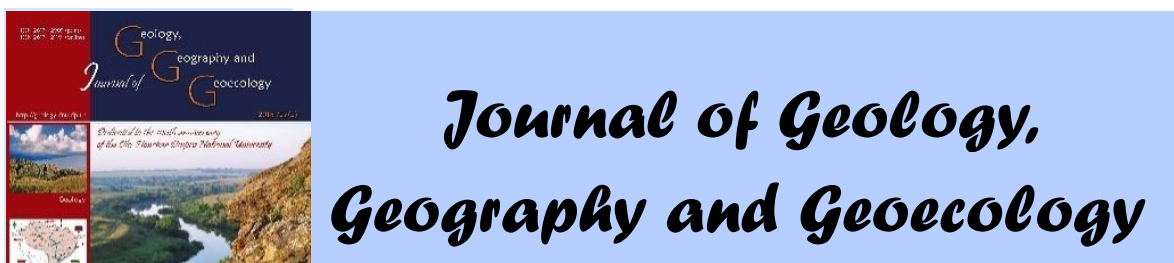

Journal home page: geology-dnu-dp.ua

\title{
River travel as a direction for the development of tourism in Ukraine
}

\author{
S.G. Nezdoyminov, O.I. Milashovska \\ Odessa National University, Odessa, Ukraine, e-mail: 2072945@gmail.com \\ Mukachevo State University, Mukachevo,Ukraine,e-mail: grs@mail.msu.edu.ua
}

Received 21.11.2018;

Received in revised form 14.01.2019; Accepted 24.02.2019

Abstract. This article explores the present state of the functioning of the market of water travel, which influences the development of the sphere of recreation and tourism in Ukraine. The internal connections between problems of modernization of the river transport sector and processes of activation of the operation of tourism business entities are revealed. It is established that in Ukraine tourist transportation by river is declining within the boundaries of the country and the freight market of cruise ships of Ukrainian shipping companies is shrinking. There is a decrease in passenger traffic in the tourist market of Zaporizhzhya, Mykolaiv, Kherson, Odessa regions and in Ukraine as a whole, compared to 2005, by almost seven times. It is determined that the market of European cruise services increases the volume of tourist trips by inland waterways due to the construction of river liners and investment in port infrastructure. The main factors that negatively influence the development of river travel in Ukraine are analyzed; the most important are the lack of budgetary financial resources and foreign investments aimed at modernizing the tourist infrastructure by the construction of a river cruise and smalltonnage passenger fleet. Future directions of development of river trips and cruise tourism on the main waterways of Ukraine are proposed. The emphasis is placed on the necessity to develop a set of measures that ensure the activation of tourist traffic in river transport enterprises in the regions of Ukraine, the formation of an attractive climate for investment in the market for river cruises. It is determined that the introduction of modern instruments for managing tourist traffic on water transport requires the development of program measures for the revival of river passenger transport, modernization of tourist infrastructure. Development of river tourist trips in Ukraine will be facilitated by the development of a strategy for modernization of river ports and the construction of modern river passenger transport, the development of the freight market, attracting investment by international cruise companies and Ukrainian tour operators on the basis of public-private partnership. It is necessary to provide state support to domestic companies that carry out modernization and construction of new-generation passenger ships and small-tonnage passenger fleets to provide regional water transportation of tourists, their recreational services, to develop tourist trips and transportation on the Dnieper and the Danube, as well as water tourist routes between coastal tourist centres of the Black Sea.

Keywords: river tourist trips, cruise tourism, recreation, water transport, tourist infrastructure.

\section{Річкові подорожі як напрямок розвитку туризму в Україні}

\section{С.Г. Нездоймінов, О.І. Мілашовська}

Одеський національний економічний університет, Одеса, Україна, е-таil: 2072945@gmail.com Мукачівський державний університет, Мукачево, Украӥна, е-таil: grs@mail.msи.еdи.иа

Анотація. Досліджено сучасний стан функціонування ринку водних туристичних подорожей, що впливають на розвиток сфери рекреації та туризму в Україні. Розкрито внутрішні зв'язки між проблемами модернізації сектору річкового транспорту та процесами активізації діяльності суб'єктів туристичного бізнесу. Встановлено, що в Україні зменшуються туристичні перевезення річковим транспортом в межах кордонів країни та скорочується фрахтовий ринок круїзних суден українських судноплавних компаній. Спостерігається скорочення пасажирообороту водного транспорту на туристичному ринку Запорізького, Миколаївського, Херсонського, Одеського регіонів та в цілому по Україні, у порівнянні з 2005 роком, майже у сім раз. Визначено, що ринок європейських круїзних послуг нарощує обсяги туристичних подорожей внутрішніми водними шляхами за рахунок будівництва річкових лайнерів та інвестування в портову інфраструктуру. Проаналізовано основні фактори, що негативно впливають на розвиток річкових подорожей в Україні, найбільш вагомими $є$ відсутність бюджетних фінансових ресурсів та закордонних інвестицій, спрямованих на модернізацію туристичної інфраструктури, у будівництво річкового круїзного та малотоннажного пасажирського флоту. Запропоновано напрями розвитку річкових подорожей та круїзного туризму на основних водних шляхах України. Привернуто увагу на необхідність розробки комплексу заходів, що забезпечують активізацію туристичних перевезень на підприємствах річкового транспорту в регіонах 
України, формування інвестиційної привабливості ринку річкових круїзів, відродженню туристичних подорожей на водному шляху р. Дніпро. Визначено, що впровадження сучасних інструментів управління туристичними перевезеннями на водному транспорті, вимагають розробки програмних заходів щодо відродження річкового пасажирського транспорту, модернізації туристичної інфраструктури. Розвитку річкових туристичних подорожей в Україні, буде сприяти розробка стратегії модернізації річкових портів та будівництва сучасного пасажирського транспорту, розвитку фрахтового ринку, залучення інвестицій міжнародних круїзних компаній та українських туроператорів на засадах державно-приватного партнерства. Необхідно забезпечити державну підтримку вітчизняним компаніям, що здійснюють модернізацію та будівництво пасажирських суден нового покоління, малотоннажного пасажирського флоту для забезпечення регіональних водних перевезень туристів, їх рекреаційного обслуговування, розвивати географію туристичних подорожей та перевезень по Дніпру та Дунаю, а також водні туристичні маршрути між туристичними центрами узбережжя Чорного моря.

Ключові слова: річкові туристичні подорожі, круїзий туризм, рекреація, водний транспорт, туристична інфраструктура.

Introduction. The latest trends in socio-economic development, globalization and competition in the travel market need their own resources, promotion of tourism enterprises and water transport concerning activation of internal reserves. The development of the market for river tourist trips can encourage enterprises of the tourism business to attract additional investments and the formation of new directions of recreational activities. There are unique historical and cultural monuments and other tourist objects and recreational facilities in the regions of Ukraine that attract tourists, which can be an important source of income for local and regional budgets and which can ensure the competitiveness of tourism services and tourism development, provided there is effective coordination between the enterprises of water transport and business tourism, cultural institutions and public authorities. The European vector of economic reform, strengthening demand for quality travel services, price competitiveness of subjects of the tourist business and market transformation of the cruise market requires the activation of the operation of river transport enterprises to ensure tourist traffic on the waterways of Ukraine. The problems of the development of the market of river cruise services require the development of a programme of measures for the modernization of the port and tourist infrastructure, the construction of new-generation passenger ships and smalltonnage passenger fleet, to meet the needs of tourists concerning tourist trip organization, transportation by the Dnieper and Danube, as well as the revival of passages between touristic centers of the Black Sea coast.

Modern processes of organizing tourist travel by waterways have been investigated by foreign specialists, among whom are Mohd Nasir, F., Hanafiah, M.H. (Mohd Nasir, and Hanafiah, 2017), who studied the socio-economic, environmental and cultural problems of river cruises; the impact of cruise tourism on the economic development of territorial communities was analyzed by T. MacNeill, D. Wozniak (MacNeill, Wozniak, 2017), and the reluctance of cruise enterprises to report fully on social and environmental issues was investigated by de Grosbois, D. (de Grosbois, 2016). According to researchers, the cruise market is divided into two segments - sea and river cruises. In comparison with sea cruises, river cruises are also becoming more popular among tourists and contribute to the growth of the economies of a variety of countries. The number of river cruise passengers worldwide rose by $10 \%$ from 2008 to 2013 , compared with $7 \%$ for the cruise industry as a whole (Accor Hotel, 2016). According to Dragin, Jovičći and Bošković (Dragin, Jovičći and Bošković, 2010), there are several factors that define market trends in river cruises, including pricing, due to competitiveness between tourist enterprises in reducing the prices of their tours and tourist attractions, and factors of supply and demand in new segments in terms of safe travel and several others. As underlined by Tsiotas, D., Niavis, S. and Sdrolias, L.: "Geography is an integral part of the cruise industry, since cruises are carried out in geographic space and, thus, are subject to spatial and geomorphologic constraints. However, the cruise literature lacks studies on geographic aspect of interactions that exist between ports and cruise enterprises». (Tsiotas, Niavis and Sdrolius, 2018).

A significant contribution to the development of theoretical and practical problems in the functioning of the river transport sector of Ukraine, was made by Pidlisny, P. (Pidlisny, 2016), the direction of the organization of tourist services by river transport enterprises were investigated by Golubkova, I.A. (Golubkova, 2017); Steba, A.A. and Mikhailova, Yu.V. (Steba and Mikhailova, 2017) conducted an analysis of factors affecting the shipping enterprise in the regional market of passenger transportation; Hodya, I. (Hodya, 2016) draws attention to the business processes of the subjects of the cruise market, which should be aimed at finding non-price factors of the competitiveness of the cruise tourism product. Antonenko, I. Ya. and Melnyk, I. L. (Antonenko and Melnyk, 2015) proposed a mechanism for managing innovations in Ukrainian enterprises of the river cruise business, etc. Overall, their findings 
prove the necessity of development of river cruise shipping, international integration of tourism enterprises, innovation and investment projects forming a tourist product and tourist services on recreational waterways of Ukraine. However, researchers have not covered the problem of provision of tourist services in water transportation in the regions of Ukraine, which indicates the need for further research in this area. Thus, according to the World Economic Forum, our country occupies only 71st place in the rating of competitiveness of tourism infrastructure, and our country occupies 93rd place according to the indicator "port infrastructure" (The Global Competitiveness Report, 2017-2018). In accordance with the economic reforms strategy in Ukraine, the main tasks of state transport policy are the support and development of water transport at the modern technological, ecological, social levels in order to meet the needs of Ukrainian society and the increase the competitiveness of the country's tourist services on the world market.

The aim of the article is to identify problems of river tourist travel on the waterways of Ukraine and to define the conditions for dynamic balanced social and economic development of the tourist industry, the proper use of the advantages of domestic natural and recreational resources in the service of tourists. On the basis of this research, we hope to determine the directions of activation of transport enterprises for tourist transportation and to formulate practical recommendations for the development of river tourist trips in Ukraine.

Material and methods of research. To study macroeconomic indicators of the institutional transport sector of the economy and its impact on the development of river tourist traffic, we used the following: the methodology of statistical monitoring of water transport statistics on the analysis of the dynamics of the main indicators by types of transportation; passenger river transport in general in Ukraine and by type of traffic, passenger river transport in regional terms, capital investment in the water transport sector, state and fixed assets, as well as methods of statistical analysis of indicators on the structure of tourist flow by type of tourism and the costs of tourism enterprises concerning organization of transportation of tourists by water. In the course of research, the methods of analysis and synthesis, systematization and generalization (for clarification of problems concerning modernization of cruise infrastructure, maintenance of tourist services, and systematization of key aspects of river travel development) were used.

Results and analysis. Ukraine's rivers have a fairly high navigable potential, and the length of waterways suitable for exploitation is about 6,200 $\mathrm{km}$. The main navigable roads are the Dnipro River - 1,205 thousand $\mathrm{km}$ and its tributaries the Desna River - $520 \mathrm{~km}$ and the Pripyat River - $60 \mathrm{~km}$, as well as the Danube River - $160 \mathrm{~km}$ and partly the Southern Buh River - $155 \mathrm{~km}$. On the waterways of Ukraine, there are 12 river ports, which have an infrastructure for tourist transportation services. However, despite having extensive water transport potential, Ukraine is in a low position among the countries with the smallest share of transportation by rivers - less than 1\% (Po Dnipru, po Buhu: problemy i perspektyvy rozvytku vodnoho transportu, 2016). Regular water connections with Belarus in the upper reaches of the Dnipro River and the Pripyat River and transport along the Desna River have practically ceased, which is associated with the abandonment of the mentioned rivers in the area. It is worth noting that in 2014 the resource base of river ships of Ukraine was 1648 units, of which $20 \%$ were unsuitable for operation. The existing infrastructure of river berths (stations) does not meet modern international technical specifications and standards and is used only for 5$10 \%$ of its capacity. The vast majority of river ports were developed in the Soviet era (Stratehichnyi plan rozvytku richkovoho transportu na period do 2020 roku. Nakaz Ministerstva infrastruktury Ukrainy 18 hrudnia 2015, № 543, 2015). The lack of a modern legislative framework for the functioning of river transport, lack of funds for state financing of infrastructure development and the lack of interest of private investors in participating in its development have created a threat to the development of the potential of river transportation of tourists. Over the past 25 years, the passenger traffic by river has decreased by 40 times. In the country only 115 ships out of 2.5 thousand remain.

Research on the world experience of river trip development indicates that for the successful functioning of the market, comprehensive development of passenger shipping and effective coordination of actions of state authorities and private and non-residents, and cooperation of shipping companies with cruise tourism operators are necessary. The main challenges in the current conditions of activity of the water transport sector are the formation of investment mechanism of construction of the smalltonnage passenger fleet, rent of river passenger ships in the external freight market. The analysis of statistics on the distribution of investment proceeds in 2016 showed that the water transport sector accounted for 233. 8 million hryvnas or $9 \%$ of the total amount of capital investment in the transport industry. But the volume of capital 
investments in the river sector passenger transport was only $0.3 \%$ of the total amount of infrastructure investment and clearly needs additional financial resourcesfor the comprehensive modernization and development of the river infrastructure passenger fleet (Table 1).

Table 1. Capital investment of enterprises by the types of economic activity "Transport, storage, postal and courier activities" (20122016).

\begin{tabular}{|l|c|c|c|c|c|c|}
\hline \multirow{2}{*}{ By industry and types of transport } & 2012 & 2013 & 2014 & 2015 & 2016 \\
\cline { 2 - 7 } & \multicolumn{5}{|c|}{ In actual prices, million hryvnas } \\
\hline $\begin{array}{l}\text { Transport, warehousing, postal and courier } \\
\text { activities, including: }\end{array}$ & 32807.9 & 18833.3 & 15498.2 & 18704.0 & 25107.8 \\
\hline Water transport : & 117.3 & 132.6 & 204.8 & 302.5 & 233.8 \\
\hline Cargo sea transport & 27.5 & 83.9 & 100.3 & 33.9 & 48.4 \\
\hline Passenger river transport & 0.4 & $\ldots{ }^{1}$ & $\ldots{ }^{1}$ & $\ldots$ & 0.8 \\
\hline Freight river transport & 74.2 & 44.5 & $\ldots{ }^{1}$ & 268.3 & 184.7 \\
\hline
\end{tabular}

Data are not disclosed in order to ensure compliance with the requirements of the Law of Ukraine "On State Statistics" regarding the confidentiality of statistical information. Source: Transport i zv"yazok Ukrayiny - 2016 r: statystychnyy zbirnyk (2017)

Total passenger traffic amount in 2016 by all types of transport of Ukraine made up 102.2 billion pas.km., which is $105.4 \%$ of the volume in 2015 and indicates positive dynamics on passenger traffic and domestic tourism in general (Fig. 1). Passenger traffic is the total amount of passenger load, which is equal to the sum of products of the number of passengers (group of passengers) at the distance of their carriage, measured in passenger-kilometers (by sea transport - in passenger-miles).

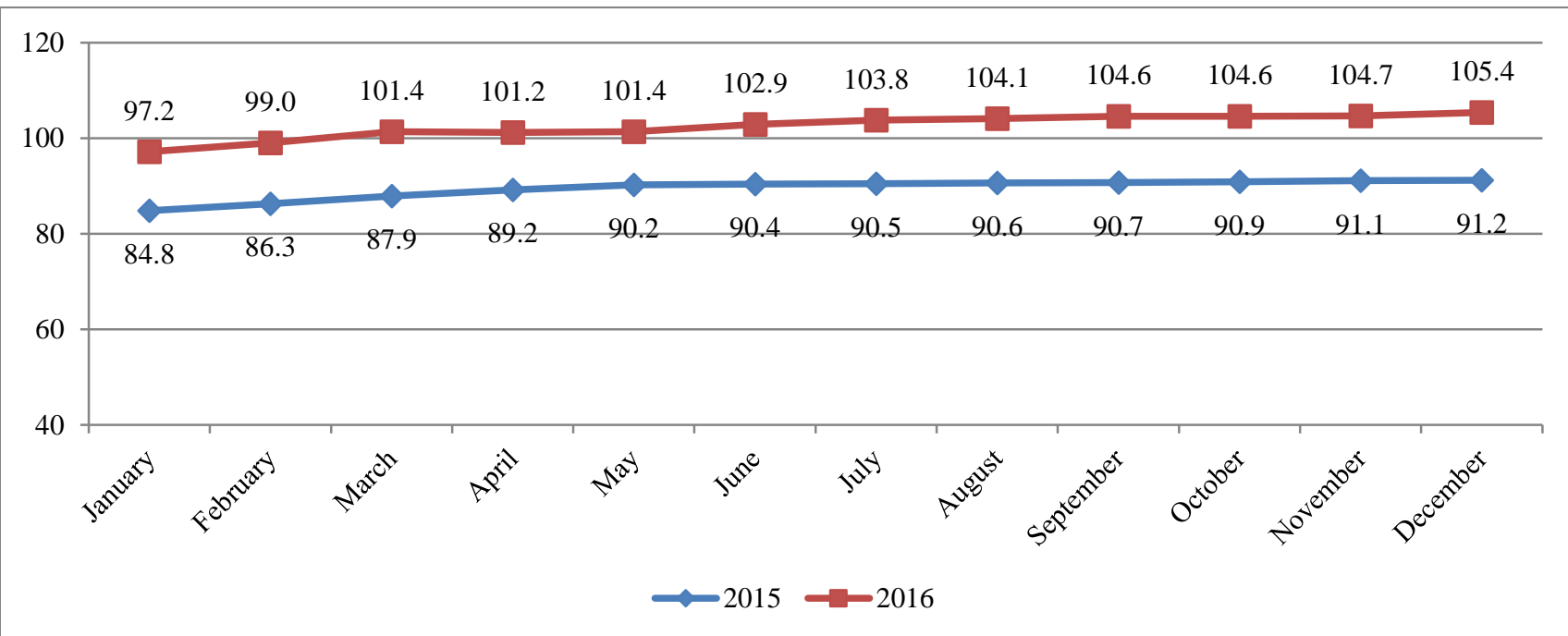

Fig. 1. Passenger traffic of transport enterprises in 2016 (in \% to the corresponding period of the previous year, as a result of growth) Source: Transport i zv"yazok Ukrayiny - 2016 r: statystychnyy zbirnyk (2017)

In 2016, 4854.4 million passengers used the services of passenger transport, or $94,0 \%$ of the volume of 2015 (Table 2). As we see, the transport of passengers by water was also declined by $17 \%$ compared with 2015. But in 2017, we have positive dynamics in relation to increase of passenger traffic of river transport by types of connection, in general, in Ukraine by 55. 9\% compared to 2016 (Table 3). In 2017 there was an increase of traffic due to tourist transportation of small tonnage and fleet, the total number of river passenger traffic was 562.9 thousand people, which was $25.5 \%$ more than in 2016 (Kilkist perevezenykh pasazhyriv za vydamy transport, 2018).

The further development of water tourism travel, in our opinion, activates tourist traffic in the country in general. Experts point out the need to develop the natural potential of tourism in Ukraine, which can be the basis for the development of internal and external geotourism (Khomenko, Isakov and Manyuk, 2018). So according to the data of the World Economic Forum, Ukraine is currently using less than a third of its available tourist and recreational potential. According to expert estimates, upon the full exploitation of Ukraine's tourism potential, budgets of all levels may amount up to 10 billion US dollars annually, based on receipts from countries co-dimensional with Ukraine in terms of tourist and recreational potential (Ekonomika rehioniv u 2015 rotsi: novi realiyi i mozhlyvosti v umovakh zapochatkovanykh reform, 2016). 
Table 2. Passenger transportation by type of transport in 2016

\begin{tabular}{|c|c|c|c|c|}
\hline Types of transportation & \multicolumn{2}{|c|}{ Passenger traffic } & \multicolumn{2}{c|}{ Passengers transported } \\
\hline & million pass. km & as \% of 2015 total & million & as \% of 2015 total \\
\hline $\begin{array}{c}\text { Total by types of transport, } \\
\text { incl.: }\end{array}$ & 102239.4 & 105.4 & 4854.4 & 94.0 \\
\hline railway & 36954.0 & 104.5 & 389.5 & 99.9 \\
\hline automobile & 34488.0 & 99.7 & 2025.0 & 90.0 \\
\hline water & 30.4 & 136.3 & 0.5 & 83.1 \\
\hline air & 15525.1 & 136.6 & 8.3 & 131.3 \\
\hline
\end{tabular}

Source: Pidsumky roboty transportu v 2016 rotsi (2017)

Table 3. Passenger traffic of river transport by type of connection (th. pass. km) for $2000-2017$

\begin{tabular}{|c|c|c|c|c|c|c|c|c|c|c|c|c|}
\hline $\begin{array}{c}\text { By type of } \\
\text { connection }\end{array}$ & 2000 & 2005 & 2010 & 2011 & 2012 & 2013 & 2014 & 2015 & 2016 & $\begin{array}{c}2017 \\
2017 \\
\text { Increase } \\
\text { compared } \\
\text { to 2016, } \\
\%\end{array}$ \\
\hline international & - & 31117.4 & 24053.0 & 26073.0 & 24277.9 & 17208.3 & 20047.8 & 2682.1 & 7813.2 & 12836.0 & 64.3 \\
\hline internal & 26727.3 & 22593.8 & 17550.8 & 18404.4 & 15220.4 & 16314.2 & 4753.3 & 5358.4 & 4740.9 & 6731.1 & 41.9 \\
\hline $\begin{array}{l}\text { In general, } \\
\text { in Ukraine }\end{array}$ & 26727.3 & 53711.2 & 41603.8 & 44477.4 & 39498.3 & 33522.5 & 24801.1 & 8040.5 & 12554.1 & 19567.1 & 55.9 \\
\hline
\end{tabular}

Source: Transport i zv"yazok Ukrayiny - 2017 r: statystychnyy zbirnyk (2018)

Globalization and integration of the processes of providing services in the international tourist market, and the growth of the tourist flow have caused demand for the transportation of tourists to tourist and recreational resources and the organization of cruise travel on the main European river routes. An important indicator of the development of tourism is the volume of tourist flow, which quantitatively reflects the constant arrival of tourists to a country (region) or the departure of tourists abroad for a certain period of time. Investigation of the structures and tourist flow of the country indicates the presence of potential in relation to development of certain segments of the tourism market. The structure of tourist flow for the types of tourism in Ukraine in 2015 was distributed as follows: the total number of tourists serviced - 2,019,576 people (100. 00\%), inbound tourism - 15,159 people $(0.75 \%)$; outbound tourism $-1,647,390$ people (81. 57\%); domestic tourism - 357,027 people (17. 68\%). The volume of domestic tourism is decreasing in general in the country, in 2012 it was $24.00 \%$ and in 2015 it was 17. 68\% (Nezdoiminov and Andrieieva, 2017). In 2016, Ukraine was visited by more than 13. 3 million foreign citizens, of which 172. 8 thousand people made tourist trips, 13. 0 million people came for private reasons, and the number of Ukrainian citizens travelling abroad, amounted to 24. 0 million people. In 2017, the number of domestic tourists increased by $33.6 \%$, but the share of domestic tourism in the total volume of tourist flow was only 16. 9\% (Ofitsinyi sait
Derzhavnoi sluzhby statystyky Ukrainy. Turystychni potoky, 2018).

The potential market demand of domestic tourists for the organization of water trips on the river Dnieper should be developed. Studies show that the amount of passenger transportation by river transport on the Dnieper has increased 5 times compared to 2013. We should draw attention to the development of new trends in passenger traffic on the Dnieper - one-day tours, in 2016120 thousand passenger-day trips under a tourist program were carried out. Analysis of sources of statistics on the cost of tour operators for services by type of transport in the production of tourism product in 2016, gives reason to believe that the most popular are water tours for tourists of Dnipropetrovsk, Zaporizhia, Kharkiv, Odessa, Cherkasy regions and Kyiv. The distribution of expenditures of tourism enterprises of Ukraine for services of transportation of tourists by types of transport in $2012-2016$ indicates their total increase and equals 207. 6\% of the volume of 2012, and by water transport an almost threefold increase due to the demand of tourists for cruises abroad. However, the reduction in the number of passenger vessels that were fit to operate has led to a reduction in the cost of tourism enterprises for the transport of tourists by waterways in Odessa region, which is a seaside region, and in 2016 it was 4. 22\% of the expenditure in 2012. (Turystychna diyal'nist' v Ukrayini u 2016 rotsi: statystychnyy zbirnyk, 2017). At the same time, the statistical data research concerning costs of entities engaged in sightseeing activities show that there is the demand from tourists for excursions by water 
transport in Odessa, Cherkasy, Vinnytsia regions, and that the proportion of the cost of transportation of tourists in the water transport sector in 2016 was $31.51 \%$ of total expenditure on transport services (Table 4).

Providing tourist services and organizing water trips along the Dnipro River and the Danube River on the cruise programs is ensured by the shipping companies "Chervona ruta" and PJSC "Ukrainian Danube Shipping Company" (UDSC), which have 8 ships with a total capacity of 1,618 passenger seats. UDP has 4 cruise passenger ships and 2 excursion ships. Cruise fleet UDSC provides transportation on tourist routes and Passau - Vienna - Budapest - Passau, Passau - Vienna - Budapest - Vilkove Passau. For the period $2014-2016,42$ thousand passengers were transported.

Table 4. Distribution of expenditures of subjects carrying out excursions providing water transport services in 2016 by regions of Ukraine (ths. UAH).

\begin{tabular}{|c|c|c|c|}
\hline \multirow{2}{*}{ Ukraine and regions } & \multicolumn{2}{|c|}{$\begin{array}{c}\text { Distribution of expenses of subjects carrying out excursion activities } \\
\text { for transportation services }\end{array}$} \\
\cline { 2 - 4 } & $\begin{array}{c}\text { Total } \\
\text { transport } \\
\text { service costs }\end{array}$ & Water transport & $\begin{array}{c}\text { Specific weight of expenses for } \\
\text { transportation of tourists by water } \\
\text { transport in the total volume, } \%\end{array}$ \\
\cline { 2 - 4 } & 1294.2 & 407.8 & 31.51 \\
\hline Ukraine, incl.: & 87.4 & 7.8 & 8.92 \\
\hline Vinnytsia & 205.0 & 191.4 & 93.37 \\
\hline Odessa & 231.1 & 208.6 & 90.26 \\
\hline Cherkasy & 2016 & & \\
\hline
\end{tabular}

Source: Turystychna diyal'nist' v Ukrayini u 2016 rotsi: statystychnyy zbirnyk (2017)

Cruise ships PJSC "UDSC" carry out tourist transportation on the most competitive market of Danube river cruises in Europe. Annually there is an increase of this market by $5-7 \%$. On the Danube, transportation of tourists is carried out by about 230 river ships. In 2015, general transportation in the Danube Delta made up about 83 thousand tourists transported, which is $93 \%$ of the amount of 2014.The cruise ships of JSC
"UDSC" did not enter the Ukrainian part of the Danube Delta in 2016-2017. In volume of domestic passenger traffic on the Danube River in 2013-2016, the river fleet of Ukraine was considerably inferior to those of Romania and Bulgaria in international tourist traffic and made up $6 \%$ of the total volume of international tourist traffic on the Danube River (Table 5).

Table 5. The dynamics of domestic carrier's passenger transportation on the Danube River in 2013 - 2016

\begin{tabular}{|c|c|c|c|c|c|c|c|c|c|c|c|c|}
\hline \multirow[b]{2}{*}{ Indexes } & \multicolumn{3}{|c|}{2013} & \multicolumn{3}{|c|}{2014} & \multicolumn{3}{|c|}{2015} & \multicolumn{3}{|c|}{2016} \\
\hline & 究 & 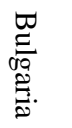 & 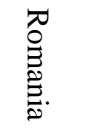 & 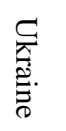 & 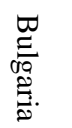 & 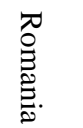 & 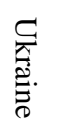 & 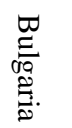 & 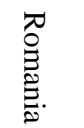 & 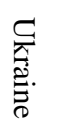 & 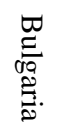 & 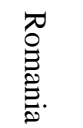 \\
\hline $\begin{array}{l}\text { Number of passenger } \\
\text { ships in service, (units) }\end{array}$ & 6 & 5 & 6 & 6 & 13 & 8 & 6 & 14 & 6 & 6 & 14 & 6 \\
\hline $\begin{array}{l}\text { Number of passengers } \\
\text { transported within the borders of } \\
\text { the country (thousand people ) }\end{array}$ & 7.0 & - & 173.0 & 4.0 & 2.0 & 150.0 & 7.0 & 5.0 & 169.0 & 3.0 & 5.0 & 156.0 \\
\hline $\begin{array}{l}\text { Number of transportations of } \\
\text { passengers in overseas traffic } \\
\text { (thousand people ) }\end{array}$ & 8.0 & 20.0 & - & 5.0 & 24.0 & 6.0 & 1.0 & 89.0 & - & 7.0 & 89.0 & - \\
\hline
\end{tabular}

Source: Statistika Dunayskogo sudohodstva v 2013-2016 (2016)

Considering the state of passenger traffic on the Danube River, we will pay attention to their main types:

- international cruise lines on craft vessels (river cruises), based on tourist cruises in the Upper Danube and cruises in the Danube Delta;

- short national and international liner transportations without cabins (liner services), based on lines from the Danube tourism centers (Vienna, Budapest, Bratislava);
- transportation on ships operating without a scheduled (non-scheduled services) in the main tourist centers.

Passenger transportation on cabin vessels is the most dynamic part of the Danube shipping; Growth of passenger traffic on the cruise lines of the Upper Danube for $2012-2016$ was $72 \%$. Over the past 15 years, the European cruise vacation industry has significantly expanded and has strong tendencies of growth. On the Danube River, it was 
reflected, above all, by the number of new passenger cruise ships. So for the period from 2012 to 2016, the river cruise fleet increased by 68 units $(54.5 \%)$ and is 192 cruise liners, while the total number of passenger seats increased by 60. $0 \%$ (Table 6). In the total volume of cruise passenger traffic, $30 \%$ of traffic is connected with the ports of departure / arrival of the Rhine Island and fall on the line of the Upper Danube (Nablyudenie za ryinkom dunayskogo sudohodstva: itogi $2016 \mathrm{~g}$, 2016). At the same time, the cruise passenger fleet of the PJSC
"UDSC", which operates on the Upper Danube with foreign tourists, for this period decreased by 2 units. But unlike in 2015, the navigational season of 2016 brought PJSC "UDSC" profit in the amount of more than 800 thousand EUR. Moreover, three quarters of this amount was provided by excursion services for tourists, the rest - accompanying services. In general, for passenger transportation, the revenues of PJSC "UDSC" for 2016 amounted to about 3 million EUR (Zavoevyivaem Evropu vozrastnyim flotom, 2017).

Table 6. Dynamic of development of the cruise fleet potential on Danube River for 2012 - 2016

\begin{tabular}{|c|c|c|}
\hline Year & Vessel quantity, units & $\begin{array}{c}\text { Seat quantity, thousand } \\
\text { units }\end{array}$ \\
\hline 2012 & 124 & 19980 \\
\hline 2013 & 137 & 22300 \\
\hline 2014 & 150 & 24700 \\
\hline 2015 & 170 & 28100 \\
\hline 2016 & 192 & 31973 \\
\hline 2016 by $2012, \%$ & 54.5 & 60,0 \\
\hline
\end{tabular}

Source: Nablyudenie za ryinkom dunayskogo sudohodstva: itogi 2016 g. (2016)

So, the modern European cruise services market demonstrates the increasing volume of tourist traffic, due to the greening of transport by waterways, the development of "green" cruise routes in the Danube Delta, and improvement in the quality of services. In our country, general transport of passengers and tourists by river transport is declining; the freight market by the number of cruise ships of Ukrainian shipping companies is also falling. According to state statistics, there is an almost sevenfold reduction in passenger travel market of Zaporizhzhya, Mykolaiv, Kherson, Odessa regions and in Ukraine in whole, compared with 2005 (Table 7). Data on passenger traffic by river in Ukraine in 2016-2017 was not covered by state statistical surveys.

Table 7. Passenger traffic by river transport in the regions of Ukraine in $2000-2015$, mln. pas.km.

\begin{tabular}{|l|c|c|c|c|c|c|c|c|}
\hline Ukraine and regions & 2000 & 2005 & 2010 & 2011 & 2012 & 2013 & 2014 & 2015 \\
\hline Ukraine & 26.7 & 53.7 & 41.6 & 44.5 & 39.5 & 33.5 & 24.8 & 8.0 \\
\hline Regions : & & & & & & & & \\
\hline Dnipro & 0.9 & 1.4 & - & 0.3 & 0.3 & 0.6 & 0.4 & 0.5 \\
\hline Zaporizhia & 6.8 & 6.7 & 0.6 & 1.3 & 1.4 & 1.0 & 0.9 & 1.2 \\
\hline Kyiv & - & 0.0 & 0.0 & 0.1 & 0.1 & 0.1 & 0.01 & - \\
\hline Mykolaiv & 2.5 & 21 & - & 0.6 & 0.4 & 0.4 & 0.4 & 0.3 \\
\hline Odessa & - & 31.6 & 24.5 & 26.2 & 24.7 & 17.6 & 20.3 & 2.9 \\
\hline Ternopil & - & 0.2 & 0.2 & 0.2 & 0.3 & 0.2 & 0.3 & 0.3 \\
\hline Kherson & 8.7 & 4.6 & - & 2.2 & 2.1 & 1.7 & 2.1 & 2.4 \\
\hline Chernihiv & 0.5 & 0.5 & 0.3 & 0.3 & 0.3 & 0.3 & 0.3 & 0.2 \\
\hline City of Kiev & 7.3 & 6.6 & 16.0 & 13.3 & 9.9 & 11.6 & 0.1 & 0.2 \\
\hline
\end{tabular}

Source: Transport i zv"yazok Ukrayiny - 2015 r: statystychnyy zbirnyk (2016)

If we trace the dynamics of foreign border river passenger transport across the state border of Ukraine, we can note that in comparison with 2000, this movement dropped three times, and from 2005 the entry of foreign tourists from Romania and from 2015 passengers from Belarus, who travelled by river waterways of Ukraine was stopped (Table 8). Thus, the segment of the foreign tourism market for river transport through the border regions of Ukraine, the Danube (Bulgaria, Romania) and Pripyat (Belarus) rivers and further organization of travel water or auto tourist routes are not involved in between in native tourism. 
Table 8. Entry of foreign passenger water transport across the state border of Ukraine for $2000-2016$ (ships)

\begin{tabular}{|c|c|c|c|c|c|c|c|}
\hline $\begin{array}{c}\text { Land borders } \\
\begin{array}{c}\text { Lassenger transport traffic in } \\
\text { all areas, units }\end{array}\end{array}$ & 708 & 424 & 836 & 1119 & 417 & 258 & 233 \\
\hline Incl. by border area & & & & & & & \\
\hline Romanian & 508 & - & - & - & - & - & - \\
\hline Belarusian & - & - & 2005 & 222 & 22 & - & - \\
\hline Sea & 200 & 424 & 628 & 897 & 395 & 258 & 233 \\
\hline
\end{tabular}

Source: Transport i zv"yazok Ukrayiny - 2016 r: statystychnyy zbirnyk (2017)

Analyzing statistical information of foreign trade of water transport services, we should pay attention to the fact that the Ukrainian river transport enterprises did not carry out hire of foreign fleet concerning transportation and maintenance of Ukrainian tourists and passengers in 2016, and also we see a surplus on maritime transport tourists (Table 9).

Table 9. Exports and imports of water transport services in 2016 (thousand US dollars)

\begin{tabular}{|c|c|c|c|}
\hline By types of transport services & Export services & Import of services & Balance \\
\hline $\begin{array}{c}\text { passenger sea } \\
\text { transport services }\end{array}$ & 139.0 & 17.2 & 121.8 \\
\hline $\begin{array}{c}\text { passenger river } \\
\text { transport services }\end{array}$ & 2732.8 & - & 2732.8 \\
\hline
\end{tabular}

Source: Transport i zv"yazok Ukrayiny - 2016 r: statystychnyy zbirnyk (2017)

The lack of budgetary funds to finance the modernization of passenger water transport, river infrastructure and the lack of interest of private investors in participating in its development have created a threat to the development of water transport and led to the decline in the river transport of tourists along the waterways of
Ukraine, as evidenced by the data on the degree of wear and tear of the main means of the industry, which in 1997 reached 97.9 percent (Table 10). In 2016, there was already a tendency for the renewal of fixed assets, mainly due to port infrastructure, for the construction and purchase of a passenger fleet, the money was not paid.

Table 10. Main means of the enterprise by type of activity "Transport, warehouse" for the period of $2012-2016$

\begin{tabular}{|c|c|c|c|c|c|}
\hline \multirow{2}{*}{ Main means } & \multicolumn{5}{|c|}{ Transport, warehouse } \\
\cline { 2 - 6 } & 2012 & 2013 & 2014 & 2015 & 2016 \\
\hline $\begin{array}{c}\text { Putting into operation of } \\
\text { new main means, mln }\end{array}$ & 29111 & 12071 & 11914 & 9925 & 23280 \\
\hline $\begin{array}{c}\text { Degree of depreciation of } \\
\text { main means, percent }\end{array}$ & 96.5 & 96.7 & 97.9 & 51.7 & 50.8 \\
\hline
\end{tabular}

Source: Transport i zv"yazok Ukrayiny - 2015 r: statystychnyy zbirnyk (2016)

At the same time, investments in the development of the cruise industry in the ports of Europe for the period 2015 - 2018 make up to 5.2 billion EUR. 30\% of total amount of investments will be directed to the construction of 10 cruise liners for European cruise lines and the modernization of the port infrastructure (Cruise Lines International Association (CLIA), 2016). The European river cruise sector is increasing by about $16 \%$ annually and this affects the number of passengers and profitability, especially in the market of Germany - the undisputed leader of the market for recreation. Sales of river cruises are growing faster than sales of ocean-going cruises. Tourist traffic on the main rivers of Europe is also growing, new operators are emerging in the market, the old (the largest river cruise lines) are regularly restored or expanding their fleet by building new generations of liner. More than half a million passengers ( $80 \%$ of them are European and $20 \%$ from North America) take European river cruise holidays each year. Tourists take river cruises, mainly in Europe, China, Southeast Asia, Russia, Ukraine and Egypt (David Mc, A. B., 2016).

Considering the modern trends of inland travel, we should note that a positive development in passenger traffic in 2017 was that the shipping company "NIBULON" (Mykolaiv) was able to restore regular passenger travels on the hydrofoil vessels between the Dnieper and Southern Bug. Over a year, more than 24,000 passengers and tourists were able to transfer by high-speed "missiles" during flights on the 
Dnieper River in Kyiv, Kaniv, Kremenchug, Cherkasy, Nikolayev and other Ukrainian cities. The company passenger fleet consists of four vessels (two ships of the "Voskhod" type, passenger capacity of 77 people and two vessels of the "Polissya" type, passenger capacity of 53 people). To provide transportation, the last two ships purchased by the company were upgraded: multimedia systems, video surveillance and notification systems, etc. were installed. In 2017, tourist transportation on the route Ochakiv Kinburskaya Spit - Ochakiv was organized, in further plans of the company - restoration of passenger transportation to Odessa, Zhelesniy Port and Skadovsk. To increase the volume of tourist traffic between the cities of the Black Sea and the upper part of the Dnieper (Dnipro, Kremenchug, Zaporozhye, Cherkasy, Kiev and others), it is planned to purchase ships of the type "catamaran". To expand the channels for the implementation of tourist services, the company "NIBULON" plans to launch a system for selling tickets through the Internet. The development strategy of the company involves the construction of its own new-generation passenger ships and small passenger lines to develop water transportation between settlements on the Dnieper, as well as tourist transportation between large Ukrainian cities on the Black Sea coast. To this end, the company is conducting a full-scale reconstruction of the shipyard "NIBULON" in such a way that in the future it will have two streaming shipbuilding and repair lines on its territory: for the passenger and specialized fleet ("NIBULON" vidkryvaie vodne pasazhyrske spoluchennia Dniprom I Pivdennym Buhom, 2018).

A revival of tourist trips is observed on the Dnipro River. According to the published information on the results of navigation in 2017 on the Dnipro, compared with 2016, the total number of vessel passages increased by $13 \%$. At the same time, the number of passenger ships increased by $32 \%$, yachts - by $3 \%$ (Shliuzuvannia suden na r. Dnipro, 2018). Another promising direction of inland tourist traffic is organizing "river-sea tours", by waterways along the Danube River and Dnieper River visiting the Ukrainian Danube Delta.

During the period from 2010 to 2014, the activities of international cruise liners visiting ports of Ukraine increased by $40 \%$, and the number of cruise tourists - by 53. 4\% (Nezdoiminov and Andrieieva, 2017). The company "Chervona Ruta" organized cruises of "river-sea" type, along the route Kyiv-OdessaYalta-Kyiv. After the Crimean annexation, international cruises and companies stopped shipping operations to the Crimean ports, which changed the navigation and tourist routes of the river cruise fleet. In the navigation 2016-2017, the port of Ust - Dunajsky was the main port for receiving Ukrainian and foreign cruise liners. Cruise activities in the port are provided by two foreign operator companies "GTA - Sky - Ways" and "Phoenix Reisen", whose vessels navigate the route Passau - Vilkove - Passau, calling at ports in Romania, Bulgaria and Slovakia. In Ukraine, tourists are offered tours of the Danube Delta and sightseeing in the town of Vilkove. In 2016, the port received 13 passenger ships. The total number of cruise passengers was 1340 people. Among Ukrainian cruise lines, the company "Chervona Ruta", which operates a cruise ship "Princess of Dnipro", works in this direction. In 2017, the "Princess of Dnipro" made 10 cruises with foreign tourists, connecting the Danube with the Dnieper. Starting at the Romanian port of Fetesti, the ship moved along the Danube, tourists visited Izmail, Vilkove and Odessa, and then on the route along the Dnipro River. Regional tourism companies participate in the maintenance of cruises. Tourists are offered excursion services in the stopover cities: Kherson, Zaporizhia and Dnieper, the cruise finishes in the capital of Ukraine. The return cruise visited the same ports. During the cruise navigation period, the port of Ust-Dunajsky received 27 passenger ships and 4,532 tourists, which provides grounds for increasing the tourist potential of the recreational areas of the Lower Danube (Ukrainskiy Port v Vilkovo prinyal uje bolee, tyisyachi inostrannyih turistov, 2016).

Summarizing our research, we note that the revival of tourist trips on inland waterways of Ukraine will contribute to the development of a long-term state development strategy for river transport. Strategic measures should also be taken for the following goals ; modernization of cruise infrastructure; introduction of EU standards for water tourists; the revival of river tourist and excursion routes, geographical specialized tours along smaller rivers; integration of river routes into the transport scheme of the European route E40. The first step in the development of domestic tourist trips is the development of modern small passenger ship building in Ukraine. The state and regional institutions in the sphere of transport and tourism should determine the prospects for the development of the market for tourist transportation by ships of the "river-sea" class, assess the tourist and recreational load in protected areas and objects of the tourist infrastructure of the Ukrainian part of the Danube Delta, and ensure adoption of regulatory and legal 
acts on the regulation of recreational activities in this area. There is a need to amend regulatory bases and to regulate the market of transport services for tourist trips in line with the requirements of European industry standards for tourist traffic. Experts point out that in the current state of travel trips impacts the level of competitiveness in the freight market. The passenger river fleet is owned by a limited number of companies that service the market of services in tourism transportation (Okorokov, Vernyhora and Tsuprov, 2016).

Conclusions. The introduction of modern tools of management of tourist transportations along the waterways of Ukraine requires development and programmatic measures to revive river connections, building a modern tourist infrastructure. Development of the market of river travel transportation will contribute to the development strategy of revival of navigation, technical upgrading of ports and construction of a modern river passenger transport, development of the freight market, and attraction of investments of international cruise companies and Ukrainian tour operators on the basis of public-private partnership. It is necessary to provide support to domestic companies that develop construction of a small passenger fleet for the organization of regional water transport of tourists and provision of their recreational services. So a set of measures for modernization of travel and transport infrastructures, effective coordination of activities of enterprises of the river transport and tourism industry, to be implemented by state management bodies, will ensure the competitiveness of tourism services and development of national tourism.

\section{References}

Antonenko, I., Melnyk, I. 2015. Mekhanizm upravlinnya innovatsiynym kruyiznym turystychnym produktom [Mechanism of innovative cruise tourism products managing]. Ekonomicnij Casopis - XXI - Economic Annals - XXI, Vol. 1-2(2), 5962 (in Ukrainian).

Accor Hotels Group. 2016. The New Wave: River Cruises. Hotel Industry Trends. Retrieved from: http://www.accorhotels-group.com/en/news/thenew-wave-river-cruises.pdf (in English).

David, Mc A. B. 2016. The cruise industry: past, present and future. Journal of Tourism. Research, 14, 145158. Retrieved from: http://jotr.eu/pdf files/V14.pdf\#page=151 (in English).

Dragin, A., Jovičći, D., Bošković, D. 2010. Economic Impact of Cruise Tourism along the Paneuropean Corridor VII. Economic Research-Ekonomska Istraživanja, 23(4), 127-141_ (in English). Ekonomika rehioniv u 2015 rotsi: novi realiyi i mozhlyvosti $\mathrm{v}$ umovakh zapochatkovanykh reform. 2016. [The region's economy in 2015: new realities and opportunities in terms of reforms initiated] Kyiv, NISD (in Ukrainian).

Cruise Lines International Association [CLIA]. 2016. The Cruise Industry. Contribution of Cruise Tourism to the Economies of Europe 2015 Edition. Retrieved from:

https://www.cruiseexperts.org/media/2280/cliacontribution-of-cruise-tourism-to-theeconomiesof-europe-2015-report.pdf (in English).

Golubkova, I. A. 2017. Diialnist PrAT «Ukrainske Dunaiske Paroplavstvo» yak odyn iz aspektiv rozvytku nishovoho sektoru kruiznoi industrii $\mathrm{v}$ Ukraini. [The activity of PJSC "Ukrainian Danube Shipping Company" as one of the aspects of the development of the niche sector of the cruise industry in Ukraine] Retrieved from: https://www.sworld.com.ua/konfer-vuz5/vuz-117onmu.pdf\#page=76 (in Ukrainian).

Grosbois, D. 2016. Corporate social responsibility reporting in the cruise tourism industry: A performance evaluation using a new institutional theory based model. Journal of Sustainable Tourism, 24(2), 245- 269. https://doi 10.1080/09669582.2015.1076827 (in English).

Hodia, I. 2016. Rozvytok richkovoho kruiznoho turyzmu v Ukraini: mynule i sohodennia. [The development of river cruise tourism in Ukraine: the past and present]. Retrieved from: http://eehb.dspu.edu.ua/article/view/101428 (in Ukrainian).

Khomenko, Y., Isakov, L. and Manyuk, V. 2018. On the development of geotouristic routes on the objects of the Precambrian Rock Association of the Western Priazovia. Journal of Geology, Geography and Geoecology, 27(2), 244-260. Retrieved from: https://doi.org/10.15421/111849 (in English). Kilkist perevezenykh pasazhyriv za vydamy transport. 2018._[Number of passengers transported by type of transport]_Retrieved from: https://ukrstat.org/uk/operativ/operativ2018/_u.ht m (in Ukrainian).

MacNeill, T., Wozniak, D. 2018. The economic, social, and environmental impacts of cruise tourism. Tourism Management, 66, 387-404 (in English).

Mohd Nasir, F., Hanafiah, M. H. 2017. River cruise impact towards local community: An Exploratory Factor Analysis approach. Journal of Tourism, Hospitality \& Culinary Arts, 9(2), 1-14 (in English).

Nablyudenie za ryinkom dunayskogo sudohodstva: itogi 2016 g. 2017. [Monitoring the Danube shipping market: results of 2016] Retrieved from: http://danubecommission.org/uploads/doc/publicat ion/Market observation 2016/ru Market_2016.pdf (in Russian).

Nezdoiminov, S. H., Andrieieva, N. M. 2017. Doslidzhennia turystychnoho rukhu na vodnomu transporti $v$ Ukraini. [Studies of tourist traffic on the water transport in Ukraine]. Retrieved from: http://mmi.fem.sumdu.edu.ua/sites/default/files/m mi2017_1_205_212.pdf (in Ukrainian). 
«NIBULON» vidkryvaie vodne pasazhyrske spoluchennia Dniprom i Pivdennym Buhom. 2017. ["NIBULON" opens a water passenger connection between the Dnieper and the Southern Bug] Retrieved from: http://www.nibulon.com/news/novinikompanii/nibulon-vidkrivae-vodnepasazhirskespoluchennya-na-pivdni-ukraini.html (in Ukrainian).

Ofitsiinyi sait Derzhavnoi sluzhby statystyky Ukrainy. Turystychni potoky. 2018 [Official site of the State Statistics Service of Ukraine. Tourist flows. 2018] Retrieved from: http://www.ukrstat.gov.ua/ (in Ukrainian).

Okorokov, A.M., Vernyhora, R.V., Tsuprov, P.S. 2016. Richkovyi transport Ukrainy: suchasnyi stan ta perspektyvy vykorystannia [The river transport of Ukraine: the current state and prospects of use] Retrieved from: http://tstt.diit.edu.ua/article/view/85886 Ukrainian).

Pidlisnyi, P. 2016. Vnutrishnii vodnyi transport: istoriia, problemy, napriamy rozvytku. [Inland water transport: history, problems, directions of development] Retrieved from: http://uaekonomist.com/archive/2016/1/Pidlisnyj.pdf (in Ukrainian).

Pidsumky roboty transportu v 2016 rotsi. 2017. [Results of transport in 2016] Retrieved from: http://www.ukrstat.gov.ua/operativ/menu/menu_u/ tr.htm (in Ukrainian).

Po Dnipru, po Buhu: problemy i perspektyvy rozvytku vodnoho transport. 2016. [On the Dnieper, on the Bug: problems and prospects of water transport development] Retrieved from: http://agravery.com/uk/posts/show/po-dnipru-pobugu-problemi-i-perspektivi-rozvitku-vodnogotransportu (in Ukrainian).

Shliuzuvannia suden na r. Dnipro. 2018. [Shrimping ships on the Dnipro River]. Retrieved from: http://uprom.info/ru/news/other/infrastruktura/shly uzuvannya-suden-na-richtsi-dnipro-u-2017-rotsizroslo-na-13/ (in Ukrainian).

Statistika Dunayskogo sudohodstva v 2013-2016 gg. 2016. [Statistics Danube navigation in 2013-2016] Retrieved from: http://www.danubecommission.org/uploads/doc/R U.pdf (in Russian).

Steba, A. A., Mikhailova, Y. V. 2017. Faktory, shcho vplyvaiut na diialnist sudnoplavnoho pidpryiemstva na rehionalnomu rynku morskykh pasazhyrskykh perevezen [Factors that affect activities of a shipping company in the regional market of sea passenger transportation] Retrieved from:

http://www.daemmt.odesa.ua/index.php/daemmt/a rticle/view/94 (in Ukrainian).

Stratehichnyi plan rozvytku richkovoho transportu na period do 2020 roku. Nakaz Ministerstva infrastruktury Ukrainy 18 hrudnia 2015 № 543. 2015. [Strategic river transport development plan for the period up to 2020. Order of the Ministry of Infrastructure of Ukraine December 18, 2015 № 543] Retrieved from: http://mtu.gov.ua/files/Стратегія\%20річкового \% 20Додаток $\% 20$ до\%20наказу\%20543.pdf Ukrainian).

Semenukha, R. 2017. Richkovyi transport Ukrainy: vyidemo na vodu chy siademo na milynu? [River transport of Ukraine: shall we get into the water or sit down on the shallows?] Retrieved from: https://dt.ua/promyshliennost/richkoviy-transportukrayini-viydemo-na-vodu-chi-syademo-namilinu-.html (in Ukrainian).

The Global Competitiveness Report 2017-2018. 2018. Retrieved from: http://www3.weforum.org/docs/GCR2018/ 05FullReport/TheGlobalCompetitivenessReport20 18.pdf (in English).

Transport i zv"yazok Ukrayiny - 2015 r: statystychnyy zbirnyk. 2016. [Transport and Communications of Ukraine - 2015. Statistical digest of the State Statistics Service] Kyiv, State Statistics Service of Ukraine, 67-68 (in Ukrainian).

Transport i zv"yazok Ukrayiny - 2016 r: statystychnyy zbirnyk. 2017. [Transport and Communications of Ukraine - 2016. Statistical digest of the State Statistics Service] Retrieved from: https://ukrstat.org/uk/druk/publicat/kat_u/publ8_u. htm (in Ukrainian).

Transport i zv"yazok Ukrayiny - 2017 r: statystychnyy zbirnyk. 2018. [Transport and Communications of

Ukraine - 2017. Statistical digest of the State Statistics Service] Retrieved from: https://ukrstat.org/uk/druk/publicat/kat_u/publ8_u. htm (in Ukrainian).

Tsiotas, D., Niavis, S., Sdrolias, L. 2018. Operational and geographical dynamics of ports in the topology of cruise networks: The case of Mediterranean. Journal of Transport Geography, 72, 23-35 (in English).

Turystychna diyal'nist' v Ukrayini u 2016 rotsi: statystychnyy zbirnyk. 2017. [Tourist activity in Ukraine in 2016 : Statistical Yearbook ] Kyiv: State Statistics Service of Ukraine (in Ukrainian).

Ukrainskiy port $\mathrm{v}$ Vilkovo prinyal uje bolee, tyisyachi inostrannyih turistov. 2016. [The Ukrainian port in Vilkovo has already received over a thousand foreign tourists] Retrieved from: http://cfts.org.ua/news/2016/07/15/ukrainskiy_port _v_vilkovo_prinyal_uzhe_bolee_tysyachi_inostra n nykh turistov 35160 (in Russian).

Zavoevyivaem Evropu vozrastnyim flotom. 2017. [We conquer Europe with an ageing fleet] Retrieved from:http://cfts.org.ua/articles/zavoevyvaem_evro pu_vozrastnym flotom intervyu_s rukovoditele mukrainskogo_dunayskogo_parokhodstva 1149 (in Russian). 